DOI: https://10.15407/kvt197.03.051

UDC 577.34:616-006:519.876.5

BONDARENKO M.A., PhD (Phys and Math), Assistant Professor, the Department of Medical and Biological Physics and Medical Informatics e-mail: bondaren.koma3007@gmail.com

KNIGAVKO V.G., DSc (Biology), Professor, Head of the Department of Medical and Biological Physics and Medical Informatics e-mail: vknigavko@gmail.com ZAYTSEVA O.V., DSc (Biology), Professor, the Department of Medical and Biological Physics and Medical Informatics e-mail: olgvaszay@gmail.com RUKIN A.S., PhD (Phys and Math), Senior Lecturer of the Department of Medical and Biological Physics and Medical Informatics e-mail: aleksej.rukin@gmail.com Kharkiv National Medical University 4, Nauky av., Kharkiv, 61022, Ukraine

\title{
MATHEMATICAL MODELING OF DNA DAMAGES IN IRRADIATED CELLS AT DIFFERENT OXYGENATION DEEREES
}

Introduction. In radiotherapy, the degree of oxygenation of tumors is of vital importance. Tumors with greater oxygenation are much more responsive to radiation therapy than tumors with significant hypoxia: well-oxygenated tumors react $2.5 \ldots 3$ times better. Mathematical modeling of DNA damage of irradiated cells at different degrees of their oxygenation is of current interest.

The purpose of the paper is to develop a mathematical model of DNA damage in irradiated cells at different degrees of their oxygenation; to study the dependence of the number of radiation damages of DNA per unit volume of the irradiated medium on the radiation dose and the concentration of oxygen in the medium; to estimate the cell cycle duration depending on the oxygen concentration.

Results. A mathematical model of oxygen effect in cells in the case of irradiation by X-rays or gamma-radiation is proposed. On the basis of this model, the dependence of the number of radiation DNA damages in the unit volume of the irradiated medium on the radiation dose and the concentration of oxygen in the medium is obtained. Triple damage to DNA molecules is determined by primary radiation damage and attacks of two radicals of oxygen on the DNA molecule. 
The effect of potentially lethal lesions (PLL) on survival of cells under irradiation conditions is studied. The phenomenon of increasing the survival of tumor cells in their irradiation under hypoxia conditions is also due to the phenomenon of potentially lethal lesions. The optimal indicator of the severity of the PLL effect is the cell cycle duration. Thus, the task of modeling PLL was reduced to creation of a mathematical model that allows estimating the value of that indicator depending on the oxygen concentration.

Conclusions. The mathematical model created in the article allows estimating the number of radiation DNA damages in the unit volume of the irradiated medium on the radiation dose and the concentration of oxygen in the medium. The dependence of the cell cycle duration on the oxygen concentration was obtained.

Keywords: radiobiology, mathematical modeling, oxygen effect, oxygen enhancement ratio, DNA damage.

\section{INTRODUCTION}

The problem of influence of the degree of oxygen effect severity on radiological sensitivity of tumor cells was considered in articles, where both model systems of irradiated DNA in dilute aqueous solutions [1] and irradiated dry DNA and dry nucleoprotein $[2,3]$ were studied. More rigorous analysis of the oxygen effect is discussed for cells grown in vitro $[4,5]$.

In radiotherapy, the degree of oxygenation of the tumor is vital [6]. Since the 1950 s [7] it has been repeatedly demonstrated that tumors with the greater oxygenation are significantly more responsive to radiation therapy than tumors with significant hypoxia [8-11]. The presence of molecular oxygen significantly increases the effectiveness of radiation therapy in comparison with anoxia and hypoxia. It is known that well-oxidized tumors respond to radiation 2.5-3.0 times better [12], hence, the effect of treatment is potentially enhancing.

Historically, oxygen was called a "dose-changing agent": it turned out that in order to achieve a predetermined level of survival under conditions of hypoxia and under oxygenation, the dose ratio was constant irrespective of the chosen survival rate $[5,13]$. This ratio of doses in hypoxic conditions and in conditions of sufficient oxygenation, which causes the same biological effect, is called the oxygen enhancement ratio (OER). For large single doses of X-ray or gamma radiation OER usually takes values from 2.5 to 3.0 ; for radiations with intermediate values of linear energy transfer (LET) the values of OER are from 1.5 to 2.0; for radiations with high values of LET - 1.0, that is the influence of oxygen does not manifest.

In the dependence curve of OER on the partial pressure of oxygen [14-16] (Fig. 1), the half-maximum sensitivity is demonstrated at partial pressure of oxygen $\mathrm{p} \approx 3 \mathrm{~mm}$ $\mathrm{Hg}$, at the same time the maximum value of OER is usually achieved at partial pressures $\mathrm{p}>20 \mathrm{~mm} \mathrm{Hg}$ with a slight further increase that essentially does not change the character of this curve $[6,17]$. Experiments conducted on cells, yeast and bacteria correspond to the same general curve of OER, which rapidly increases and saturates, corresponding roughly to a hyperbolic dependence on the oxygen tension $[6,13,18]$.

If the relative radiosensitivity for completely anoxic tumor cell culture is taken as 1 , the addition of even $0.5 \%(\mathrm{p}=3 \mathrm{~mm} \mathrm{Hg})$ oxygen to the system increases the radiosensitivity of the cells up to 2 . The sensitivity average between the fully hypoxic and the completely normoxic state is achieved for an oxygen tension of about $3 \mathrm{~mm}$ $\mathrm{Hg}$, corresponding to approximately $0.5 \%$ oxygen. This is more than 10 times lower than the partial pressure of oxygen in normal tissues. This value of $0.5 \%$ was called the oxygen "k-value" and was obtained from the oxygen "k-curve" of the relative radiosensitivity plotted on the graph as a function of the oxygen pressure (Fig. 1). 


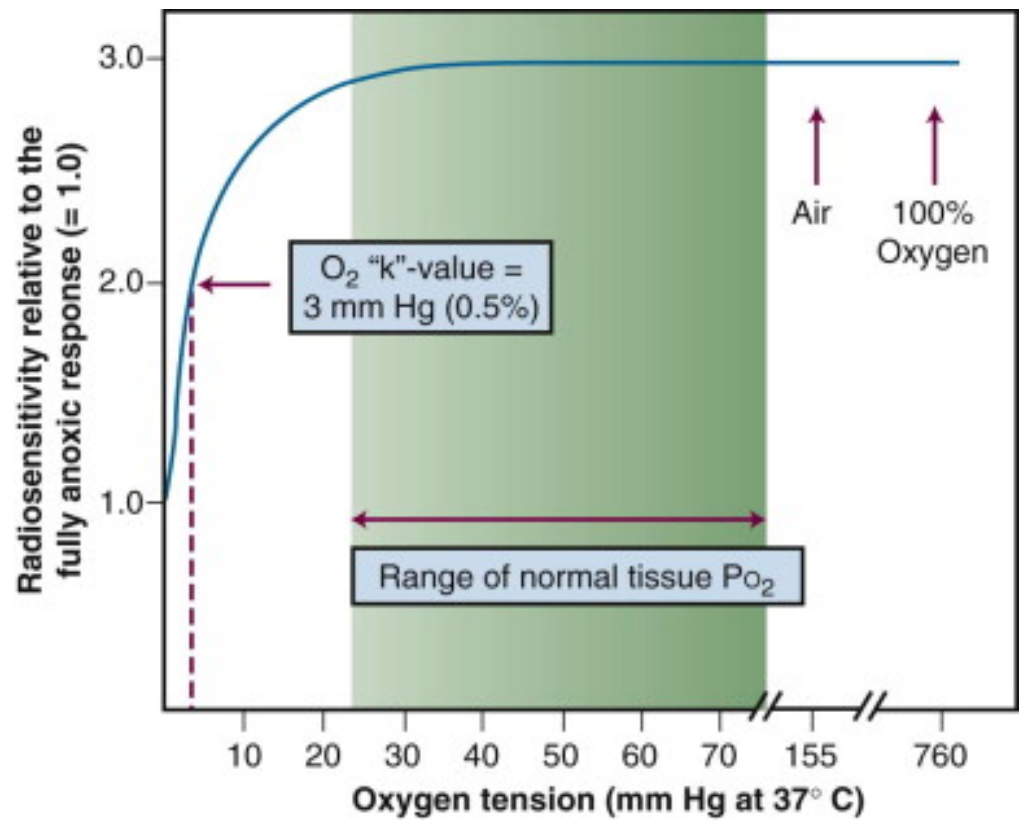

Fig. 1. Dependence of radiosensitivity of tumor cells on oxygen partial pressure (oxygen tension) (k-curve of oxygen)

When the oxygen concentration reaches approximately $2 \%(\mathrm{p}>20 \mathrm{~mm} \mathrm{Hg})$, the cells react in the same way as if they are completely oxygenated (i. e., the radiosensitivity is approximately 3.0). The highlighted zone in Fig. 1 represents the range of normal human tissues oxygen concentrations.

For the oxygen effect to occur, molecular oxygen must be present prior to irradiation or within the first few microseconds of irradiation [6, 19]. An increase in OEF does not occur if oxygen is added within a time that exceeds this time limit. The concentration of oxygen needed to achieve maximum sensitization is quite small, which indicates the high efficiency of oxygen as a radiosensitizer. Radiochemical basis of this phenomenon is known as the oxygen fixation hypothesis $(\mathrm{OFH})[6,13,20]$.

$\mathrm{OFH}$ postulates that in the absence of oxygen the DNA can be restored to the initial (before irradiation) state by donating hydrogen from endogenous reducing agents in the cell, such as glutathione (thiol compound), which absorbs free radicals. This can be considered a type of very rapid chemical recovery. But this recovery is difficult or impossible in the presence of oxygen molecules. When a high-energy photon interacts with a biological substance, it can cause damage in several ways: directly interact with DNA, causing the event of ionization of DNA, or interact with other substances, including water, creating high-energy electrons. These ionizing electrons react with water to form highly reactive hydroxyl radicals $\left(\mathrm{R}^{\bullet}\right)$, which in turn cause damage to the DNA basis. In general, this kind of radical damage is easily chemically restored. However, when these radicals encounter molecular oxygen, they form a peroxyl radical RO2•. Such a damage is much more devastating, because it is difficult or impossible to restore $[20,21]$. 


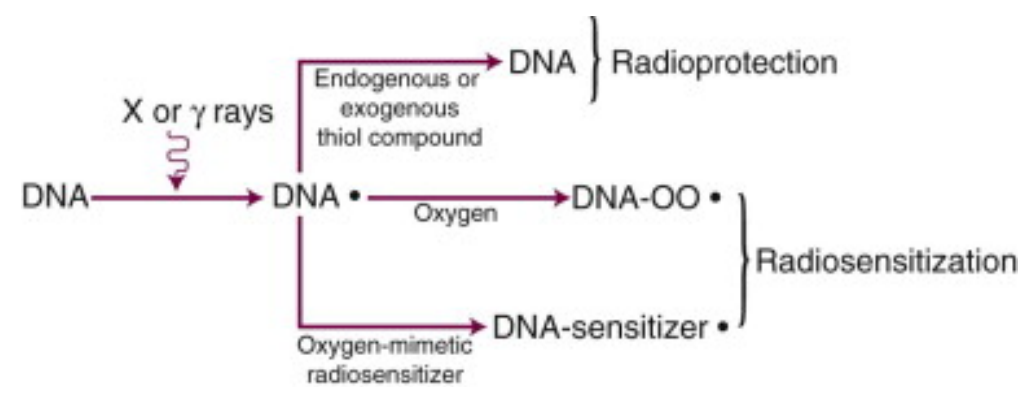

Fig. 2. Schematic representation of the proposed mechanism of oxygen influence.

Thus, the model of radical competition argues that oxygen acts as a radiosensitizer, forming peroxides in DNA that is already damaged by radiation, thereby fixing the damage. In the absence of oxygen, the DNA can be restored to the original state by hydrogen donation from endogenous reducing agents in the cell, such as glutathione. The schematic representation of the proposed mechanism is shown in Fig. 2.

\section{MATHEMATICAL MODEL OF OXYGEN EFFECT}

Taking into account the results of previous investigations of the mechanism of the oxygen effect [22-28] and classical experiments [14-16], in this work a model of DNA damage of cells during irradiation with ionizing radiation depending on the degree of oxygenation is proposed, based on a mechanistic approach to understanding this phenomenon.

Specifically, an estimation of the probability of DNA brakes formation of the irradiated cells depending on the radiation dose and on the concentration of oxygen in the irradiated medium is considered.

Let us introduce the designations. $D$ is the radiation dose; $c$ is the concentration of oxygen in the medium containing irradiated objects; $n$ is the number of potential damages per unit volume of the medium caused by irradiation; $N$ is the number of DNA breaks formed in a unit volume of medium. We assume that $n$ is directly proportional to the value of $D$. More precisely, we will assume that $n=\kappa D$, where $\kappa$ is a coefficient whose magnitude depends on the type and energy of radiation.

The question why a potential damage interacts with oxygen molecules and what kind of interaction occurs is quite complicated.

A potential damage is likely to be an excited portion of a macromolecule. As a result, it can participate in orientation interactions with an oxygen molecule. However, one cannot deny the possibility of involvement of potential damages in induction and dispersion interactions. All these interactions are characterized by the interaction energy proportional to the value $r^{-6}$, where $r$ is the distance between the interacting objects.

Thus, the interaction of a potential damage with the oxygen molecule at a selected time point can occur only in the small spherical or almost spherical region of the irradiated medium. Let $V$ be the volume, and $R$ - the radius of this region, $V=\frac{4}{3} \pi R^{3}$. 
Since potential damages are fixed on the surface of some macromolecules, their interaction with oxygen molecules can occur only due to diffusion motion and, as the result, appearance of an oxygen molecule in one of the abovementioned regions with a radius $R$ containing potential damages.

The interaction forces between oxygen molecules and other molecules of the medium (except potential damages) are obviously small (in any case, from the point of view of the processes under consideration) and can be neglected.

Let $V_{0}$ be the maximum volume of the environment in which an oxygen molecule can meet a potential damage and interact with it during a time period $T$. It is obvious that

$$
V_{0}=\frac{4}{3} \pi(u T)^{3}
$$

where $u$ is the diffusion motion velocity of the oxygen molecule.

Let us consider one molecule of oxygen from the volume and determine the probability $p$ of the fact that during the time $T$ this molecule will reach the region of interaction of the oxygen molecule and a potential damage. The volume of the region in which this interaction may occur is equal to

$$
V_{1}=\pi R^{2} u T \text {. }
$$

Then the probability that the specified oxygen molecule reacts with the potential damage equals

$$
p=\frac{V_{1}}{V_{0}}=\frac{3 R^{2}}{4(u T)^{2}} .
$$

Let $v$ be the number of oxygen molecules in the volume $V_{0}$. Then

$$
v=c V_{0} \text {. }
$$

The probability that an arbitrarily chosen oxygen molecule will not react with potential damage equals $1-p$. The probability that none of the molecules in the volume $V_{0}$ will react with potential damage is equal to $(1-p)^{\nu}$. Then the probability of transformation of a potential DNA damage into a DNA break equals

$$
p_{p}=1-(1-p)^{v} \text {. }
$$

Consequently, the number $N$ of DNA breaks per unit volume of the medium irradiated with X-ray or gamma radiation, depending on the dose of radiation $D$ and the concentration $c$ of oxygen in the medium, is determined by the formula

$$
N=n \cdot p_{p}=n \cdot\left(1-(1-p)^{v}\right)=\kappa D \cdot\left(1-(1-p)^{c V_{0}}\right) .
$$

It is clear that in the general case, the number of damages may vary, and this quantity of damages depends on the degree of oxygenation of the medium in which the cells are located. It is also clear that the probability of damage occurring at other equal conditions is the greater, the higher the degree of oxygenation of the environment. 
As is well known, in order to take into account this factor, an indicator named oxygen enhancement factor (OEF) was introduced, which shows how many times the degree of damage to the DNA at normoxia is greater than that hypoxia [22-24]. But at the same time, there is no explanation in the literature why the maximum OEF value for photon radiation cannot be more than 3 .

There is no generally accepted answer to the question. However, it can be assumed that since oxygen in water is a biradical, the maximum possible triple damage to DNA molecules is determined by both their primary radiation damage and the attack on the DNA molecule by two radicals of the oxygen molecule.

Nowadays there is increasing evidence [4] that oxygen does not always modify the dose equally. Several studies have shown that the OEF for rarely ionizing radiation is lower at low doses than at high doses. Lower OEF values for doses per single fraction in the range commonly used in radiotherapy were obtained indirectly from clinical and experimental oncology data and directly in cell culture experiments. It was suggested that lower values of OEF are the result of the age dependence of the oxygen effect, which is almost identical to the age dependence of radiosensitivity and the duration of the cell cycle. Assuming that cells in the G1 phase of the cell cycle have a lower OEF than cells in the S phase, and since cells in the G1 phase are also more radiosensitive, it can be concluded that they will be disposed to dominate in the low dose area of the cell survival curve.

We estimated the value of such an indicator as the cell cycle duration $(\tau)$ of tumor cells during reparation of double-stranded DNA breaks, depending on their degree of oxygenation. This indicator most adequately reflects the severity of the process of potentially lethal lesions (PLL) that must be taken into account in radiotherapy $[22,23]$.

In this work we assume that any factor that slows the passage of irradiated cells in the stages of the cell cycle is associated with an increase in the amount of reparation of radiation DNA damage in these cells, and this increase in the amount of DNA reparation, in turn, increases the probability of cell survival [29-31]. The assumption of the universality of the discussed effect suggests that the known phenomenon of increasing the survival of tumor cells in their irradiation under hypoxia is also associated with the phenomenon of potentially lethal lesions (PLL). From the above, it follows that the optimal indicator of severity of the PLL effect is the cell cycle duration $(\tau)$. Thus, the task of PLL modeling is reduced to the construction of a mathematical model that allows us to estimate the magnitude of this indicator.

In this work, we consider only effects caused by irradiation of cells by photon (X-ray or gamma) radiation.

Initially, under the phenomenon of PLL one meant increasing the survival of irradiated cells if they were exposed to irradiation not in the nutrient medium, but in water. Probably the most convincing explanation for this effect is the assumption that lack of a nutrient in cells causes a slowdown in the passage of cells through the stages of the cell cycle, and this slowdown leads to an increase in the volume of reparation of double-stranded breaks (DB) in the DNA of irradiated cells. In turn, increasing the amount of reparation leads to increasing of irradiated cells survival.

If we accept this interpretation of the essence of the PLL phenomenon, we can assume that it has a more universal character. Namely, it can be assumed that any factors that slow down the cell cycle increase the amount of DNA 
reparation and, consequently, increase the survival of cells. In favor of this hypothesis, one can cite the well-known phenomenon in radiotherapy, when the radiation resistance of tumor cells increases with increasing degree of hypoxia.

The above considerations are the basis for constructing a mathematical model of the PLL phenomenon.

First of all, let us decide what indicator will reflect the discussed effect most accurately. Taking into account our assumption that the degree of deceleration of the cell cycle determines the survival of irradiated cells, the duration $\tau$ of the cell cycle can be used as this indicator.

Regardless of the degree of hypoxia, the cell needs to consume a certain amount of oxygen for the separation. It is clear that the oxygen consumption rate of the cell depends on the concentration of oxygen in the pericellular medium.

Experimentally, the dependence of the rate of oxygen consumption by the cell on the concentration of oxygen in the medium is given in [23] (Fig. 3). Along the $\mathrm{X}$ axis there is the oxygen tension ( $\mathrm{pO} 2), \mathrm{mm} \mathrm{Hg}$; along the $\mathrm{Y}$ axis there is the rate of oxygen consumption, $\mu \ell$ of oxygen (under normal conditions) per minute, calculated for 106 cells.

From [23], as well as from the results of our earlier studies [24-26], it follows that the graph of this experimental dependence can be adequately approximated by two linear segments (if the tissue necrosis is not taken into account), one of these segments describing the normoxic area of the discussed function graph, and the other one - the hypoxic area (Fig. 4).

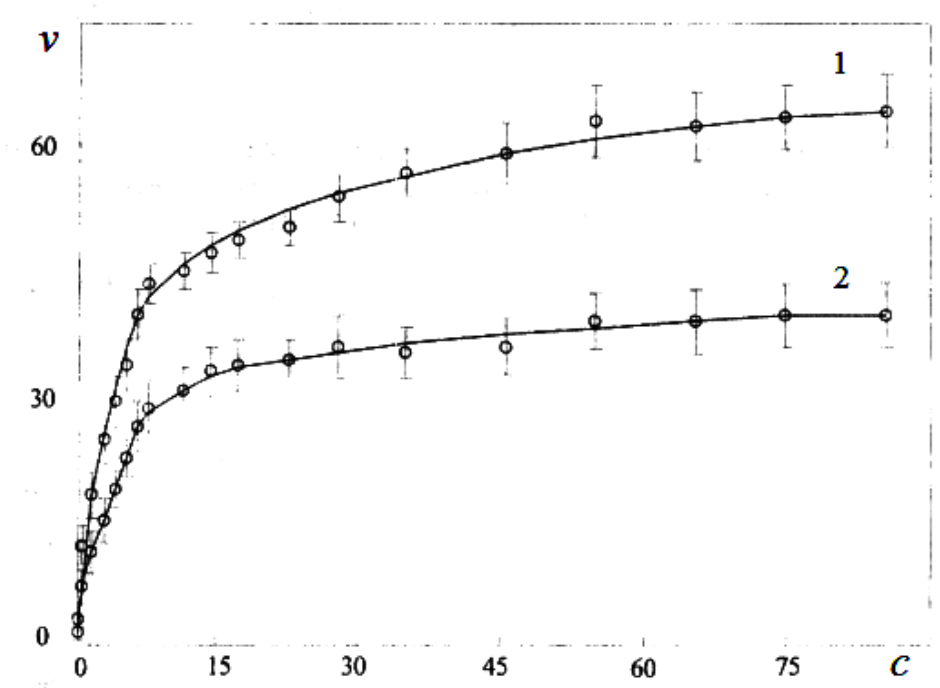

Fig. 3. Experimental dependence of the oxygen consumption rate of normoxic (1) and hypoxic (2) Chinese hamster cells on the oxygen tension in the pericellular medium. 


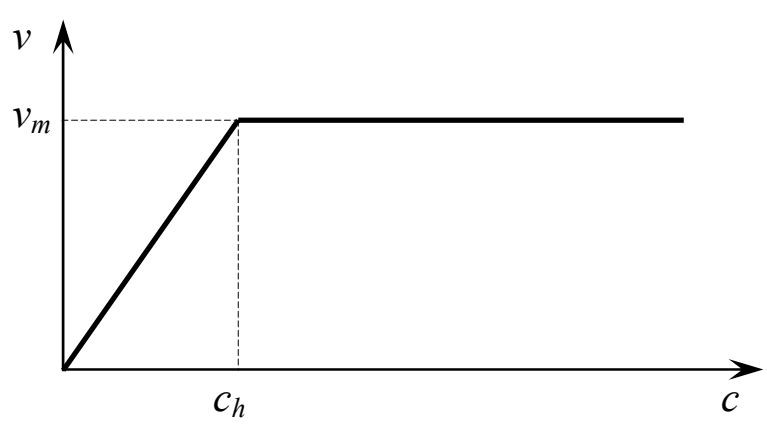

Fig. 4. Approximation of the dependence shown in Fig. 3.

The hypoxic area we are interested in is mathematically described as follows:

$$
v=\frac{v_{m} c}{c_{h}}
$$

where $v$ is the mass rate of oxygen consumption by the cell, $v_{m}$ is the maximum value (in the case of normoxia) of the value of $v, c$ is the oxygen concentration in the medium, $c_{h}$ is the threshold value of the oxygen concentration between normoxia and hypoxia.

The complexity of further modeling is determined by the fact that the value of $v$ consists of two functionally different components. One of them $\left(v_{l}\right)$ is the rate of oxygen consumption spent for maintaining the current life of the cells. This value is constant. Another component $\left(v_{p r}\right)$ is the rate of oxygen consumption spent on the preparation and implementation of cell division. This particular component is important for further modeling.

Obviously,

$$
v_{p r}=v-v_{l}=\frac{v_{m} c}{c_{h}}-v_{l}
$$

Hence at $c=\frac{c_{h} v_{l}}{v_{m}}$ the value $v_{p r}=0$ and we can write

$$
v_{p r}=\frac{v_{m}\left(c-c_{l}\right)}{c_{h}},
$$

where $c_{l}$ is the concentration of oxygen needed to maintain the cell's current activity.

Let $M$ be the mass of oxygen needed by the cell for preparation and implementation of division. It is obvious that $M=\tau \cdot v_{p r}$.

The desired value $\tau$ can be calculated using the formula and then converted using the above approximation to the following form

$$
\tau=\frac{M}{v_{p r}}
$$




$$
\tau=\frac{M \cdot c_{h}}{c-c_{p r}} .
$$

The obtained formula for evaluating the cell cycle duration of tumor cells as an index of severity of the PLL effect shows the dependence of $\tau$ on the concentration of oxygen in the medium, the threshold concentration value between normoxia and hypoxia, the oxygen concentration needed to maintain the current life of the cells, as well as the mass of oxygen necessary for the cell to prepare and implement its division.

\section{CONCLUSIONS}

A mathematical model of oxygen effect in cells is proposed in case of irradiation by $\mathrm{X}$-ray or gamma-radiation. On the basis of this model, the dependence of the number of radiation damages of DNA in the unit volume of the irradiated medium on the radiation dose and the oxygen concentration in the medium was obtained.

In general, the number of damages can be different and depends on the degree of oxygenation of the medium in which the cells are located. The probability of damage occurring at other equal conditions is the higher, the higher the degree of oxygenation of the medium.

The well-known fact that the maximum value of the OEF for photon radiation cannot be greater than 3 is explained this way. Since oxygen in water is a biradical, the triple damage to DNA molecules is determined by primary radiation damage and attacks on the DNA molecule by two radicals of the oxygen molecule.

The effect of potentially lethal injuries on survival of cells under irradiation conditions is studied. Any factor that slows down the passage of irradiated cells through the stages of the cell cycle is associated with an increase in the amount of DNA radiation damage reparation in these cells, which in turn increases the likelihood of cell survival. The phenomenon of increasing the survival of tumor cells at their irradiation under hypoxia conditions is also due to the phenomenon of potentially lethal lesions. The above suggests that the optimal indicator of the severity of the PLL effect is the cell cycle duration. Thus, the task of modeling the PLL was reduced to construction of a mathematical model that allows estimating the value of the indicator depending on the concentration of oxygen.

\section{REFERENCES}

1. Alper E. Introduction to Liquid-Liquid Extraction with Chemical Reaction. Proceedings of NATO ASI on "Mass transfer with chemical reaction in multiphase systems, Turkey. 1981. Vol. 72/73, pp. 577-611.

2. Van der Schans G.P., van Loon A.A., Groenendijk R.H., Baan R.A. Detection of DNA Damage in Cells Exposed to Ionizing Radiation by Use of Anti-single-stranded DNA Monoclonal Antibody. Int. J. of Radiat. Biology. 1989. Vol. 55(5), pp. 747-760.

3. Lücke-Huhle C., Braun A., Hagen U. Oxygen effect in gamma-irradiated DNA Z. Naturforsch B. 1970. Vol. 25(11), pp. 1264-1268.

4. M. Zeman. Biologic Basis of Radiation Oncology. Clinical Radiation Oncology (Third Edition). 2012, pp. 3-42.

5. Ewing D. The oxygen fixation hypothesis: a reevaluation. Am. J. Clin. Oncol. 1998. Vol. 21, pp. 355-361. 
6. Hall E., Giaccia A. Radiobiology For The Radiologist. 6th ed. Philadelphia: Lippincott William and Wilkins, 2006.

7. Gray L., Conger A., Ebert M., Hornsey S., Scott O. The concentration of oxygen dissolved in tissues at the time of irradiation as a factor in radiotherapy. Br. J. Radiol. 1953. Vol. 26, pp. 638-648.

8. Evans S.M., Koch C.J. Prognostic significance of tumor oxygenation in humans. Cancer Lett. 2003. Vol. 195, pp. 1-6.

9. Vaupel P, Mayer A. Hypoxia in cancer: significance and impact on clinical outcome. Cancer Metastasis Rev. 2007. Vol. 26, pp. 225-239.

10. Wilson W.R., Hay M.P. Targeting hypoxia in cancer therapy. Nat. Rev. Cancer. 2011. Vol. 11, pp. 393-410.

11. Knigavko V.G., Bondarenko M.A., Zaytseva O.V. The Generalized Mutation Theory of Oncogenesis. Journal of Clinical and Diagnostic Research. 2018. Vol. 12(11), pp. XE01-XE04.

12. Bentzen S., Gregoire V. Molecular-imaging-based dose painting - a novel paradigm for radiation therapy prescription. Semin. Radiat. Oncol. 2011. Vol. 21, pp. 101-110.

13. Howard-Flanders P, Alper T. The sensitivity of microorganisms to irradiation under controlled gas conditions. Radiat. Res. 1957. Vol. 7, pp. 518-540.

14. Koch C.J., Stobbe C.C., Bump E.A. The effect on the $\mathrm{Km}$ for radiosensitization at $0{ }^{\circ} \mathrm{C}$ of thiol depletion by diethylmaleate pretreatment: quantitative differences found using the radiation sensitizing agent misonidazole or oxygen. Radiat. Res. 1984. Vol. 98, pp. 141-153.

15. Whillans A.D.W., Hunt J.W., Whillans D.W. A Rapid-mixing comparison of the mechanisms of radiosensitization by oxygen and misonidazole in CHO cells. Radiat. Res. 1982. Vol. 90, pp. 126-141.

16. Ling C. C., Michaels H. B., Gerweck L. E., Epp E. R., Peterson E. C. Oxygen sensitization of mammalian cells under different irradiation conditions. Radiat. Res. 1981. Vol. 86, pp. 325-340.

17. Wouters B.G., Brown J.M. Cells at intermediate oxygen levels can be more important than the 'hypoxic fraction' in determining tumor response to fractionated radiotherapy. Radiat. Res. 1997. Vol. 147, pp. 541-550.

18. Chapman J.D., Dugle D.L., Reuvers A.P., Meeker B.E., Borsa J. Letter: studies on the radiosensitizing effect of oxygen in Chinese hamster cells. Int. J. Radiat. Biol. Relat. Stud. Phys. Chem. Med. 1974. Vol. 26, pp. 383-389.

19. Howard-Flanders P., Moore D. The time interval after pulsed irradiation within which injury to bacteria can be modified by dissolved oxygen: I. A search for an effect of oxygen $0.02 \mathrm{~s}$ after pulsed irradiation. Radiat. Res. 1958. Vol. 9, pp. 422-437.

20. Bertout J., Patel S., Simon M. The impact of $\mathrm{O}_{2}$ availability on human cancer. Nat. Rev. Cancer. 2008. Vol. 8, pp. 967-975.

21. Michael B.D., O’Neill P.A. Sting in the tail of electron tracks. Science. 2000. Vol. 287, pp. 1603-1604.

22. Yarmonenko S.P., Vainson A.A., Magdon E. Oxygen effect and radiation therapy of tumors. Moscow: Medicine, 1980. (in Russian).

23. Voloshina E.A., Mescherikova V.V. Oxygen effect and adaptation reactions of cells. Radiobiology. 1979. Vol. 19, no. 2, pp. 283-285 (in Russian).

24. Knigavko V.G., Bondarenko M.A., Buts V.G. Diffusion of oxygen in a malignant tumor during the early stage of its development (spheroid stage). Biophysical Bulletin. 2000. Vol. 2(7), pp. 55-59 (in Russian).

25. Bondarenko M.A., Knigavko V.G., Gordienko V.G., Protsenko E.V., Knigavko A.V. Modeling of oxygen diffusion and consumption processes in malignant tumor strands. Biophysical Bulletin. 2001. Vol. 1(8), pp. 81-85 (in Russian).

26. Knigavko V.G., Bondarenko M.A., Ponomarenko N.S., Radzishevska E.B. Mathematical simulation of oxygen diffusion and consumption in a flat malignant tumor. Ukrainian Journal of Radiology. 2008. Vol. 16, no. 1, pp. 61-65 (in Ukrainian).

27. Knigavko V.G., Bondarenko M.A. Mathematical modeling of oxygen diffusion and consumption in a malignant tumor. Biophysics. 2005. V. 30, no. 3, pp. 544-549 (in Russian). 
28. Bondarenko M., Knigavko V., Zaytseva O. Approach to evaluate the risk of cancer for different number of tumor suppressor genes in the individual. East European Journal of Physics. 2018. Vol. 5, no. 2, pp. 23-26.

29. Grimes D.R., Kelly C., Bloch K., Partridge M.A method for estimating the oxygen consumption rate in multicellular tumour spheroids. J. R. Soc. Interface. 2014. V. 11.

30. Tannock I. Oxygen diffusion and the distribution of cellular radiosensitivity in tumours. Br. J. Radiol. 1972. Vol. 45, pp. 515-524.

31. Grimes D. R., Fletcher A. G., Partridge M. Oxygen consumption dynamics in steadystate tumour models. R. Soc. Open Sci. 2014. Vol. 1.

Received 29.03.2019

\section{ЛІТЕРАТУРА}

1. Alper E. Introduction to Liquid-Liquid Extraction with Chemical Reaction. Proceedings of NATO ASI on "Mass transfer with chemical reaction in multiphase systems", Turkey. 1981. Vol. 72/73. P. 577-611.

2. Van der Schans G.P., van Loon A.A., Groenendijk R.H., Baan R.A. Detection of DNA Damage in Cells Exposed to Ionizing Radiation by Use of Anti-single-stranded DNA Monoclonal Antibody. Int. J. of Radiat. Biology. 1989. Vol. 55(5). P. 747-760.

3. Lücke-Huhle C., Braun A., Hagen U. Oxygen effect in gamma-irradiated DNA Z. Naturforsch B. 1970. Vol. 25(11). P. 1264-1268.

4. M. Zeman. Biologic Basis of Radiation Oncology. Clinical Radiation Oncology (Third Edition). 2012. P. 3-42.

5. Ewing D. The oxygen fixation hypothesis: a reevaluation. Am. J. Clin. Oncol. 1998. Vol. 21. P. 355-361.

6. Hall E., Giaccia A. Radiobiology For The Radiologist. 6th ed. Philadelphia : Lippincott William and Wilkins, 2006. $546 \mathrm{p}$.

7. Gray L., Conger A., Ebert M., Hornsey S., Scott O. The concentration of oxygen dissolved in tissues at the time of irradiation as a factor in radiotherapy. $B r . J$. Radiol. 1953. Vol. 26. P. 638-648.

8. Evans S.M., Koch C.J. Prognostic significance of tumor oxygenation in humans. Cancer Lett. 2003. Vol. 195. P. 1-6.

9. Vaupel P, Mayer A. Hypoxia in cancer: significance and impact on clinical outcome. Cancer Metastasis Rev. 2007. Vol. 26. P. 225-239.

10. Wilson W.R., Hay M.P. Targeting hypoxia in cancer therapy. Nat. Rev. Cancer. 2011. Vol. 11. P. 393-410.

11. Knigavko V. G., Bondarenko M. A., Zaytseva O. V. The Generalized Mutation Theory of Oncogenesis. Journal of Clinical and Diagnostic Research. 2018. Vol. 12(11). P. XE01-XE04.

12. Bentzen S., Gregoire V. Molecular-imaging-based dose painting - a novel paradigm for radiation therapy prescription. Semin. Radiat. Oncol. 2011. Vol. 21. P. 101-110.

13. Howard-Flanders P, Alper T. The sensitivity of microorganisms to irradiation under controlled gas conditions. Radiat. Res. 1957. Vol. 7. P. 518-540.

14. Koch C.J., Stobbe C.C., Bump E.A. The effect on the $\mathrm{Km}$ for radiosensitization at $0{ }^{\circ} \mathrm{C}$ of thiol depletion by diethylmaleate pretreatment: quantitative differences found using the radiation sensitizing agent misonidazole or oxygen. Radiat. Res. 1984. Vol. 98. P. 141-153.

15. Whillans A.D.W., Hunt J.W., Whillans D.W. A Rapid-mixing comparison of the mechanisms of radiosensitization by oxygen and misonidazole in $\mathrm{CHO}$ cells. Radiat. Res. 1982. Vol. 90. P. 126-141.

16. Ling C.C., Michaels H.B., Gerweck L.E., Epp E. R., Peterson E.C. Oxygen sensitization of mammalian cells under different irradiation conditions. Radiat. Res. 1981. Vol. 86. P. 325-340.

17. Wouters B.G., Brown J.M. Cells at intermediate oxygen levels can be more important than the 'hypoxic fraction' in determining tumor response to fractionated radiotherapy. Radiat. Res. 1997. Vol. 147. P. 541-550. 
18. Chapman J.D., Dugle D.L., Reuvers A.P., Meeker B.E., Borsa J. Letter: studies on the radiosensitizing effect of oxygen in Chinese hamster cells. Int. J. Radiat. Biol. Relat. Stud. Phys. Chem. Med. 1974. Vol. 26. P. 383-389.

19. Howard-Flanders P., Moore D. The time interval after pulsed irradiation within which injury to bacteria can be modified by dissolved oxygen: I. A search for an effect of oxygen $0.02 \mathrm{~s}$ after pulsed irradiation. Radiat. Res. 1958. Vol. 9. P. 422-437.

20. Bertout J., Patel S., Simon M. The impact of $\mathrm{O}_{2}$ availability on human cancer. Nat. Rev. Cancer. 2008. Vol. 8. P. 967-975.

21. Michael B.D., O’Neill P.A. Sting in the tail of electron tracks. Science. 2000. Vol. 287. P. 1603-1604.

22. Ярмоненко С.П., Вайнсон А.А., Магдон Э. Кислородный эффект и лучевая терапия опухолей. М. : Медицина, 1980. 247 с.

23. Волошина Е.А., Мещерикова В.В. Кислородный эффект и адаптационные реакции клеток. Радиобиология. 1979. Т. 19. Вып. 2. С. 283-285.

24. Книгавко В.Г., Бондаренко М.А., Буц В.Г. Диффузия кислорода в злокачественной опухоли на раннем этапе ее развития (этапе сфероида). Біофізичний вісник. 2000. Вип. 2(7). С. 55-59.

25. Бондаренко М.А., Книгавко В.Г., Гордиенко В.Г., Проценко Е.В., Книгавко А.В. Моделирование процессов диффузии и потребления кислорода в тяжах злокачественных опухолей. Біофізичний вісник. 2001. Вип. 1 (8). С. 81-85.

26. Кнігавко В.Г., Бондаренко М.А., Пономаренко Н.С., Радзішевська С.Б. Математичне моделювання процесів дифузії та споживання кисню у злоякісній пухлині плоскої форми. Укр. радіол. журн. 2008. Т. 16, № 1. С. 61-65.

27. Книгавко В.Г., Бондаренко М.А. Математическое моделирование диффузии и потребления кислорода в злокачественной опухоли. Биофизика. 2005. Т. 50, вып. 3. С. 544-549.

28. Bondarenko M., Knigavko V., Zaytseva O. Approach to evaluate the risk of cancer for different number of tumor suppressor genes in the individual. East European Journal of Physics. 2018. Vol. 5, No. 2. P. 23-26.

29. Grimes D.R., Kelly C., Bloch K., Partridge M.A method for estimating the oxygen consumption rate in multicellular tumour spheroids. J. R. Soc. Interface. 2014. V. 11. Article ID: 20131124.

30. Tannock I. Oxygen diffusion and the distribution of cellular radiosensitivity in tumours. Br. J. Radiol. 1972. Vol. 45. P. 515-524.

31. Grimes D.R., Fletcher A.G., Partridge M. Oxygen consumption dynamics in steady-state tumour models. R. Soc. Open Sci. 2014. Vol. 1. Article ID: 140080.

Отримано 29.03.2019 
Бондаренко М.А., канд. фіз.-мат. наук, доцент кафедри медичної та біологічної фізики і медичної інформатики e-mail: bondaren.koma3007@gmail.com

Кнігавко В.Г., д-р. біол. наук, професор, зав. кафедри медичної та біологічної фізики і медичної інформатики e-mail: vknigavko@gmail.com Зайцева O.B., д-р біол. наук, професор кафедри медичної та біологічної фізики і медичної інформатики e-mail: olgvaszay@gmail.com Рукін О.С., канд. фіз.-мат. наук, старш. викладач кафедри медичної та біологічної фізики і медичної інформатики e-mail: aleksej.rukin@gmail.com Харківський національний медичний університет пр. Науки 4, м. Харків, 61022, Україна

\section{МАТЕМАТИЧНЕ МОДЕЛЮВАННЯ ПОШКОДЖЕНЬ ДНК ОПРОМІНЕНИХ КЛІТИН ЗА РІЗНОГО СТУПЕНЯ ЇХНЬОЇ ОКСИГЕНАЦІЇ}

Вступ. У радіотерапії ступінь оксигенації пухлин має життєво важливе значення. Пухлини з більшою оксигенацією набагато сильніше реагують на променеву терапію, ніж пухлини зі значною гіпоксією: добре оксигеновані пухлини реагують в 2,5-3 рази краще. Математичне моделювання пошкодження ДНК опромінених клітин за різного ступеня їхньої оксигенації має значний інтерес.

Метою статті є розроблення математичної моделі пошкодження ДНК в опромінених клітинах за різного ступеня їх оксигенації; вивчення залежності кількості радіаційних ушкоджень ДНК на одиницю об'єму опроміненого середовища від дози опромінення та концентрації кисню в середовищі; оцінювання тривалості клітинного циклу залежно від концентрації кисню.

Результати Запропоновано математичну модель дії кисню в клітинах у разі опромінення рентгенівськими променями або гамма-випромінюванням. На основі цієї моделі отримують залежність кількості пошкоджень радіаційної ДНК в одиничному об'ємі опроміненого середовища від дози опромінення та концентрації кисню в середовищі. Потрійне пошкодження молекул ДНК визначається первинним радіаційним ураженням та атаками двох радикалів кисню на молекулу ДНК.

Вивчено вплив потенційно летальних уражень (ПЛУ) на виживання клітин в умовах опромінення. Феномен підвищення виживання пухлинних клітин у разі їх опромінення в умовах гіпоксії також зумовлено явищем потенційно летальних уражень. Оптимальним показником тяжкості ефекту ПЛУ є тривалість клітинного циклу. Отже, завдання моделювання ПЛУ зводилося до створення математичної моделі, яка дає можливість оцінити значення цього показника залежно від концентрації кисню.

Висновки. Запропоновано математичну модель кисневого ефекту в клітинах у разі опромінення їх рентгенівським або гамма-випромінюванням. На основі цієї моделі було отримано залежність числа радіаційних пошкоджень ДНК в одиниці об'єму опроміненого середовища від дози випромінювання та концентрації кисню в середовищі. Пояснено факт, що максимальне значення коефіцієнта кисневого підсилення для фотонних випромінювань не може бути більше трьох. Вивчено вплив потенційно летальних пошкоджень на виживаність клітин в умовах опромінення. Оптимальним показником вираженості ефекту потенційно летальних пошкоджень $є$ тривалість клітинного циклу. Побудовано математичну модель, що дає змогу оцінити величину цього показника залежно від концентрації кисню.

Ключові слова: радіобіологія, математичне моделювання, кисневий ефект, коефіиієнт кисневого підсилення, пошкодження ДНК. 
Бондаренко М.A., канд. физ.-мат. наук, доцент кафедры медицинской и биологической физики и медицинской информатики e-mail: bondaren.koma3007@gmail.com Книгавко В.Г., д-р биол. наук, профессор, зав. кафедры медицинской и биологической физики и медицинской информатики e-mail: vknigavko@gmail.com Зайчева O.В., д-р биол. наук, профессор кафедры медицинской и биологической физики и медицинской информатики e-mail: olgvaszay@gmail.com Рукин А.C., канд. физ.-мат. наук, старш. преподаватель кафедры медицинской и биологической физики и медицинской информатики e-mail: aleksej.rukin@gmail.com

Харьковский национальный медицинский университет пр. Науки 4, г. Харьков, 61022, Украина

\section{МАТЕМАТИЧЕСКОЕ МОДЕЛИРОВАНИЕ ПОВРЕЖДЕНИЙ ДНК ОБЛУЧЕННЫХ КЛЕТОК ПРИ РАЗНОЙ СТЕПЕНИ ИХ ОКСИГЕНАЦИИ}

Предложена математическая модель кислородного эффекта в клетках при облучении их рентгеновским или гамма-излучением. На основе этой модели получена зависимость числа радиационных повреждений ДНК в единице объема облученной среды от дозы излучения и концентрации кислорода в среде. Объяснен факт, что максимальное значение коэффициента кислородного усиления для фотонных излучений не может быть больше 3. Изучено влияние потенциально летальных повреждений на выживаемость клеток в условиях облучения. Оптимальным показателем выраженности эффекта потенциально летальных повреждений является продолжительность клеточного цикла. Построена математическая модель, которая позволяет оценить величину этого показателя в зависимости от концентрации кислорода.

Ключевые слова: радиобиология, математическое моделирование, кислородный эффект, коэффициент кислородного усиления, повреждение ДНК. 